\title{
Research of medical gases in Poland
}

\author{
Robert P Ostrowski and Emanuela B Pucko
}

\begin{abstract}
Research of medical gases is well established in Poland and has been marked with the foundation of several professional societies. Numerous academic centers including those dealing with hyperbaric and diving medicine conduct studies of medical gases, in vast majority supported with intramural funds. In general, Polish research of medical gases is very much clinical in nature, covering new applications and safety of medical gases in medicine; on the other hand there are several academic centers pursuing preclinical studies, and elaborating basic theories of gas physiology and mathematical modeling of gas exchange. What dominates is research dealing with oxygen and ozone as well as studies of anesthetic gases and their applications. Finally, several research directions involving noble gas, hydrogen and hydrogen sulfide for cell protection, only begin to gain recognition of basic scientists and clinicians. However, further developments require more monetary spending on research and clinical testing as well as formation of new collective bodies for coordinating efforts in this matter.
\end{abstract}

Keywords: Oxygen, Ozone, Gaseous transmitters, Volatile anesthetics, Noble gas, Poland

\section{Introduction}

This paper summarizes and critically reviews research of medical gases in Poland done up to the year of 2012, predominately emphasizing interesting findings and promising directions to follow. We have searched bibliographical databases such as PubMed, MEDLINE, SCOPUS, Web of Knowledge and also used Polish search engines such as Expertus with publication records for employees of medical, agricultural, and military universities and research institutes in Poland. Timeline of these records stretched from April 1974 until January 2013. Of note, search terms denoting Polish affiliations were selected. In addition searching terms/phrases comprised hyperbaric oxygen, oxygen, ozone hydrogen, hydrogen sulfide, and carbon monoxide, nitric oxide, nitrous oxide, halothane, enflurane, isoflurane, sevoflurane and desflurane, and nitrogen. Then terms denoting noble gas were applied, including but not limited to helium and xenon followed by heliox and trimix, then pefluorocarbon and sulfur hexafluoride, such as in Sonovue. In general we focused on medical gases administered as exogenous agents, keeping in mind though that some of these gases can be formed

\footnotetext{
* Correspondence: rostrowski@imdik.pan.pl

Department of Experimental and Clinical Neuropathology, M. Mossakowski Medical Research Centre, Polish Academy of Sciences, 5 Pawińskiego St, 02-106 Warsaw, Poland
}

\section{Biomed Central

endogenously and partake in human physiology. A few Polish review papers summarizing international research of different gases in medicine, including those with characteristics of gaseous transmitters, were included here as well. On numerous occasions we refer to original and review papers and commentaries written by internationally renowned experts of the subject.

\section{On the historical note}

One alchemist from Poland can be considered a father of all Polish gas research. Michael Sendivogius, born in 1566 (died in 1636) studied philosophy, geometry, astronomy, mechanics, and alchemy at Cracow Academy of Poland and honed his skills at major European universities [1]. In 1604 he was able to obtain a gaseous substance that he named "food of life", from heating salpetre, some 170 years before a major discovery of oxygen by Priestley. Apart from being an advisor to three Habsburg emperors Rudolph II, Matthias and Ferdinand II, Sendivogius received hefty remunerations from the king of Poland Sigismundus III Vasa who had a confidence in him, and was an avid amateur alchemist himself.

During partitions of the country (since 1795) Polish nationals worked in the gas research at the universities annexed by Austria, Prussia, and Russia, producing great results. Those include an invention of new methods of 
liquefying oxygen and nitrogen by Professors Karol Olszewski and Zygmunt Wróblewski of the Jagiellonian University in Cracow. They were able to liquefy these gases first time in history from stable state air in 1883. Later Wróblewski as first published the data on hydrogen's critical temperature, pressure, and boiling point (1885); both liquid oxygen and nitrogen have widespread use in medicine today [2-4]. In 1939, 21 years after regaining independence by Poland, the Institute for Maritime Medicine was erected in the coastal city of Gdynia which had started an era of maritime, diving and hyperbaric medicine. Since 1949 the Institute publishes a bulletin currently known as "International Maritime Health", indexed in Medline. Currently the Institute is part of Medical University of Gdańsk as Inter-Faculty Institute of Maritime and Tropical Medicine [5]. It houses the National Centre for Hyperbaric Medicine and DAN Europe Office Polska located in Gdynia.

Polish research institutions conducting studies of medical gases include hyperbaric medicine centers, universities and institutes throughout the country.

Amongst organizations that nurture medical gas research, are the Polish Society of Anaesthesiology and Intensive Therapy issuing an official journal "Anaesthesiology Intensive Therapy" established 1968, while the Polish Hyperbaric Medicine and Technology Society, founded in 1997, since 2004 publishes "Polish Hyperbaric Research" journal, formerly distributed in a bulletin form.

\section{Oxygen in basic and clinical studies including hyperbaric research}

The major achievement of Polish scientists are testing diagnostic applications of new parameters of oxygen physiology, thereby contributions to its understanding. As far as hyperbaric oxygen is concerned, Polish research not only indicates efficacy and clinical safety of this therapy in wound care and otorhinolaryngology, but novel mechanisms of treatment as well. It needs to be stressed however that interesting studies Polish of medical gas for diving medicine requires separate review.

Thus, one Polish group created a system based on neural network that can forecast arterial blood gas values computed from several input parameters including hemoglobin oxygen saturation [6]. Others elaborated purely mathematical model of oxygen gas exchange in the process of human respiration, that allows to examine gas exchange upon artificial oxygen ventilation and also to predict disturbances of oxygen exchange in pathological settings [7]. Polish scientists also adopted new oxygen status parameters known from literature such as oxygen extraction tension used e.g. to evaluate tissue hypoxia in diabetic children and adolescents [8].

Therapeutic action of oxygen has been reported in several studies advocating oxygen therapy at home, which improves life comfort and longevity of patients with lung diseases [9]. However in the field of neonatology it was found that oxygen increases the frequency of retinopathy of prematurity in neonates treated at $\mathrm{FiO}_{2}$ over 0.7 [10]. Another group has stated that oxygen should not exceed $40 \%$ during newborn resuscitation, and $100 \%$ oxygen is allowed only transiently [11].

In Poland it was commander Augustyn Dolatkowski, the first Polish member of Undersea \& Hyperbaric Medical Society, who pioneered in lobbying for introducing hyperbaric oxygen into clinical practice. He postulated establishing at least three hyperbaric oxygen treatment centers, including one in district of Silesia, one in Warsaw and one on the coast [12]. Around that time Poland had operated oxygen chambers for patients in Sosnowiec (1971), Warsaw (1973) and Gdynia (1974) [13]. At the present time there are several more HBO chambers in the country including at Siemianowice Śląskie (est. 2002), Wrocław (2008), Łódź and Stalowa Wola (2009), and those opened in 2012: in Łęczna (eastern Poland), and another $\mathrm{HBO}$ center in Warsaw, run by a private clinic.

Clinical studies have shown that adjunct HBO, $10 \times 2$ ATA for 1 hour, is effective in the treatment of trophic ulcerations from venous insufficiency [14]. Interestingly, $\mathrm{HBO}$ at 2.5 ATA may improve thermoregulation by rearranging microcirculation in trophic ulcerations of the crura [15]. HBO administered within 2 to 60 exposures of 70 min. at 2.5 ATA was found to limit the extent of tissue lesions and extent of amputations in diabetic foot patients [16] [17]. In larger group of patients with thermal burns HBO (2.5 ATA) reduced time to skin graft by 8 days, decreased tissue edema, risk of respiratory failure, and shortened duration of hospitalization [17]. HBO (2.5 ATA for $90 \mathrm{~min}$ ) also proved to be an effective therapeutic adjuvant in Fournier's gangrene, when given for seven days twice a day [18]. In patients with electric burns HBO (15-60 sessions) reduced infectious complications and overall mortality [19]. HBO (20 to 40 expositions per patient) cured postoperative sternal wound infection and mediastinitis in 55 patient enrolled in the clinical study [20]. Polish researchers as well found HBO beneficial for bacterial and to a lesser degree fungal otitis (14 to 45 exposures at above parameters) [21]. In other series of otorhinolaryngology cases $\mathrm{HBO}$ ameliorated hearing in $71 \%$ of patients under 18 treated for sudden sensorineural hearing loss; the authors used multiple HBO 2.5 ATA for 70 min. [22]. Furthermore, in adults $15 \mathrm{HBO}$ sessions at $250 \mathrm{kPa}\left(100 \% \mathrm{O}_{2}\right)$ alleviated chronic severe form of tinnitus compared to pharmacological therapy alone [23].

$\mathrm{HBO}$ also appears to be an effective adjunct treatment for radionecrotic type injuries including complications of neck irradiation [24]. Using thermographic approach others have found that HBO $(30-60 \times 90$ minutes at 2.5 
ATA) increases blood supply and tissue metabolism in cases of mandible osteoradionecrosis [25].

Polish preclinical HBO studies for neurological disorders aim to verify the mechanism of treatment against complex pathogenesis of neuron injury [26]. In one recent study authors demonstrated that both $\mathrm{HBO}$ and HBA (2.5 ATA for $60 \mathrm{~min}$ ) increased neuronal survivability and functional performance after 5 min global cerebral ischemia in gerbils. Authors have postulated that equivalent reduction in cell death in both treatment groups can be attributed to a lowering effect of hyperbaria on brain temperature, regardless of air or oxygen [27]. The mechanisms of HBO have been also studied in the neonatal rats subjected to $60 \mathrm{~min}$ hypoxia-ischemia (HI). The authors demonstrated that HBO administered at 2.5 ATA at 1 or $3 \mathrm{hrs}$ after $\mathrm{HI}$ reduced SOD activity in cerebral tissues while increasing GSH content and that $\mathrm{HBO}$ reduced brain damage more effectively than HBA treatment. Authors suggested that the production of free radicals was reduced with HBO and HBA, which manifested itself in decreased SOD activity [28]. When analyzing hypobaric hypoxia postconditioning the authors have found increased SOD activity and control GSH levels, which points towards distinctive molecular mechanisms triggered by each of the conditionining means.

\section{Ozone therapy}

The major achievement of Polish ozone studies was to add novel clinical data allowing to broaden ozone indications in the clinical management of orthopedic surgery and dentistry, and demonstrate the application of ozone treatment in toxicology. In addition Polish researchers indicated which bacterial species are particularly susceptible to ozone therapy for dental care.

Similar to $\mathrm{HBO}$, ozone inhibits septic processes in the wounds and facilitates wound healing; and it is believed that devising new methods of ozone administration may optimize those effects [29]. In this regard ozone was found to be prophylactic against septic complications in total hip plasty with and without cement [30]. Ozone administration was associated with completely cured bedsores in $16 \%$ of patients while in further $20 \%$ patients a significant improvement was noted as compared to the control group with traditional treatment [31]. As to lower extremities ailments ozone femoral artery injections administered for the treatment of atherosclerotic ischemia of the lower extremities more than doubled claudication distance [32]. Moreover, ozonated autohemotherapy $(50 \mathrm{ug} / \mathrm{ml})$ stimulated potentially beneficial changes in serum lipids including a decrease of total cholesterol and LDL levels in atherosclerotic ischemia of lower limbs [33]. Ozone (60 $\mu \mathrm{g}$ O3/mL i.v.) also normalized the activities of arylsulphatase, cathepsin D, acid phosphatase, and alpha-1-antitrypsin blood levels in patients with obliterative atheromatosis
[34]. In gonarthrosis patients addition of ozone at $64 \mu \mathrm{g} / \mathrm{m} 3$ $(0,032 \mathrm{ppm})$ in bath to the routine therapy reduced incidence of pain and diminished the use of analgesics [35].

Polish dental studies revealed that ozone kills number of viruses including HV1, HV2, and bacteria including Actinobacillus actinomycetemcomitans and Campylobacter gracilis and sputorum of the mouth and oral cavity; the bactericidal effects manifested themselves at 3,0 or 3,4 $\mu \mathrm{g} /$ $\mathrm{mL}$ ozone for 50-60 s [36,37]. Others have demonstrated potent oxidative effect of ozone towards Streptococcus, Staphylococcus and Enterococcus species isolated from the oral cavity [38]. While, ozone also decreases Fusobacterium nucleatum in gingival pockets [39]. The intracanal application of ozone proved to decrease periapical inflammation and caused absence of pain or exudate in root canal (HealOzone device, KaVo Co. up to 2100 ppm) [40]. Studies in 131 young patients age 11-12 revealed usefulness of ozone stopping progression of occlusal pit and fissure caries of premolar teeth with use of the device as above [41]. Moreover, in patients aged 21 till 65 ozone treatment was proposed for dentin hypersensitivity as a clinical method of eradicating bacteria from dentinal tubules thus facilitating beneficial penetration of fluoride, calcium, phosphates and tin minerals into the tooth in treatment (Heal Ozone, $\mathrm{KaVo}$ ) [42].

On the other hand several Polish studies indicate a need for close monitoring over biochemical and proteomic indices of ozone therapy as it proved to have a decomposing impact on serum tocopherols $(40-45 \mu \mathrm{l}$ per $1 \mathrm{~cm} 3$ oxygen-ozone mixture in isotonic salt solution drip) [43], and oxidized blood lipids (30 $\mu \mathrm{g} / \mathrm{mL})$ [44]. Ozone however may have a therapeutic potential in toxicology; oxygen-ozone mixture injections reduced metallothionein level and cadmium accumulation in rat kidney after cadmium acetate intoxication [45]. An early bird for investigation of molecular mechanisms of ozone therapy was the proteomic study of ozonated blood by Ciborowski et al. [44]. The products of ozonation including ROS, $\mathrm{H}_{2} \mathrm{O}_{2}$ and LOPs play not only a role of biomarkers but are mediators of subcellular mechanisms of ozone treatment. Hydrogen peroxide activates tyrosine kinase which phosphorylates NF-kB fighting immune depression. Ozone generates LOPs which unlike ROS are longer lasting and activate endothelial cells leading to increased production of NO and vasodilatation, while may mediate bone marrow stem cells' mobilization as well [46].

\section{Nitric oxide, carbon monoxide and hydrogen sulfide: gas giants and hot research spots}

Nitric oxide, carbon monoxide and hydrogen sulfide belong to the gaseous transmitters. The gases in this group can be used therapeutically although except nitric oxide, have mostly investigational status at this point. 
As for nitric oxide the established contributions of Polish researchers was to add new data on the clinical management of pulmonary hypertension and demonstrate its role oxide as gastroprotectant, and the involvement in nociception.

Inhalational nitric oxide has been a matter of investigation in cardiology of the adults and infants [47]. Patients with mitral valve and pulmonary hypertension inhaling NO (30 ppm) for 15 minutes before cardiac surgery procedures demonstrated favorable acute circulatory reaction, especially a reduction in pulmonary resistance [48]. Nitric oxide $(8,15 \pm 5,73 \mathrm{ppm})$ when inhaled upon imminent pulmonary hypertensive crisis after open heart correction in children caused a positive hemodynamic response manifested as reduced pulmonary arterial pressure and increased $\mathrm{PaO}_{2}$ [49]. Indeed nitric oxide causes pulmonary arteries to display their vasodilatatory reserve as in cases of dilated cardiomyopathy [50].

Another research approach relies on the compounds releasing $\mathrm{NO}$ or triggering its production. Donors of NO, such as 3-morpholinosyndnoimine, S-nitroso-N-acetylDLpenicillamine, nitroglycerin and $\mathrm{NO}$-aspirin have been demonstrated to act as gastroprotectants upon water immersion restraint stress [51]. Polish researchers found that NO mediated ulcer healing imparted by cholecystokinin [52]. In addition, endogenous NO has been found involved with the mechanisms of gastric preconditioning by means of 5 minute celiac artery occlusion [53]. It seems that the mechanism of $\mathrm{NO}$ mediated preconditioning can be similar to the one found in cardiac preconditioning and involve NOS, soluble guanyl cyclase and protein kinase G. Signal could be further transmitted to mitochondria via the opening of ATP-sensitive $\mathrm{K}+$ channel and inhibition of the mitochondrial permeability transition pore in mucosal cells [54].

As to nociceptive action of $\mathrm{NO}$, its endogenous donor L-arginine decreased antinociception effect of diazepam, chlordiazepoxide or clonazepam on the writhing test in mice consistent with the notion that excess $\mathrm{NO}$ produces hyperalgesia [55]. Additionally on the formalin test in rats, NO decreased spinal antinociceptive effect of clonidine but not that of baclofen [56].

Polish studies have also indicated benefits of carbon monoxide in organ transplant and preconditioning, beside studying mechanisms of toxicity upon excess CO [57]. One study has suggested that CO may be involved with the mechanisms of preconditioning, prior to organ transplant. The authors evaluated kidney transplant from $\mathrm{CO}$ poisoned donor and found prolonged tolerance of kidney to ischemia (total ischemia time was 24 hours and 35 minutes), effective urine production and uneventful clinical post transplant course. They postulated that $\mathrm{CO}$ may be responsible for preconditioning effect in clinical transplantation procedures, possibly due to anti-ischemic and anti- inflammatory properties of $\mathrm{CO}$ [58]. Indeed, $\mathrm{CO}$ was found to combat sepsis, mediate anti inflammatory effect in the liver and protects against renal ischemia-reperfusion injury [59]. Of note CO donor administration can inhibit thrombosis, through a decrease in active plasminogen activator inhibitor-1 or a decrease in fibrin generation, independently of guanyl cyclase (as in case of NO), which may prove beneficial with respect to organ transplant [60]. As reviewed by Amano et al. molecular mechanism of $\mathrm{CO}$ at therapeutic doses may involve modulating immune response in graft donors, in particular diminishing expression of MHC class II on dendritic cells and reducing APC -induced T cell proliferation, TNF- $\alpha$ and IFN- $\gamma$, and IL-2 production [61]. Furthermore CO increases HIF-1 $\alpha$ and VEGF expression as well as bcl- 2 production leading to reduced apoptosis.

$\mathrm{H}_{2} \mathrm{~S}$ is a gaseous neurotransmitter involved with longterm potentiation and smooth muscle relaxation [62]. In the living organisms $\mathrm{H}_{2} \mathrm{~S}$ forms an aqueous solution of weak acid or is present as an anion. Although administration of gaseous $\mathrm{H}_{2} \mathrm{~S}$ has been used in research, its proper dosage appears challenging (usual range 20-80 ppm) [63].

In the field of hydrogen sulfide studies Wiliński and colleagues at the Jagiellonian University have shown the immense impact of a variety of pharmacological agents on endogenous $\mathrm{H}_{2} \mathrm{~S}$ production and postulated the pharmacomodulatory role of $\mathrm{H}_{2} \mathrm{~S}$ in this setting [64]. According to their investigations Vitamin D3 at doses up to $40000 \mathrm{UI} / \mathrm{kg}$ b.w. increased tissue free $\mathrm{H}_{2} \mathrm{~S}$ concentration in the heart (by $74.1 \%$ ) and to a lesser degree in the brains and kidneys of male SJL mice [65]. The authors further demonstrated that other repeatedly administered drugs, including aspirine, acetaminophen, atorvastatin, ramipril, amlodipine, digoxin and and carvedilol, affect sulfur metabolism and $\mathrm{H}_{2} \mathrm{~S}$ [65]. Interestingly they found that aspirin (10 mg/kg b.w.) decreased $\mathrm{H}_{2} \mathrm{~S}$ levels in the brain of female albino Swiss mice (although increased in the liver) contrary to some other reports showing aspirin-induced $\mathrm{H}_{2} \mathrm{~S}$ elevation in female BALB/c and male B10.PL mice. Therefore, they postulated that $\mathrm{H}_{2} \mathrm{~S}$ production in mouse brain could be strain dependent [66]. Acetaminophen (30 mg/kg b.w.) produced marked increase in $\mathrm{H}_{2} \mathrm{~S}$ tissue concentration in the heart and kidney while decreased its levels in brains of female CBA mice [67]. In same strain of mice the effect of atorvastatin injected at a dose of 5 or $20 \mathrm{mg} / \mathrm{kg}$, remarkably increased $\mathrm{H}_{2} \mathrm{~S}$ concentration in the kidney, and also in the brain and heart at a dose of $5 \mathrm{mg} / \mathrm{kg}$, while decreased in the liver at both doses [68]. In CBA mice of both sexes, Ramipril, 5 or $10 \mathrm{mg} / \mathrm{kg}$ increased $\mathrm{H}_{2} \mathrm{~S}$ tissue concentration in mouse liver while decreased in kidney, where $\mathrm{H}_{2} \mathrm{~S}$ by itself has been identified as inhibiting ACE [64]. Experiments with cardiological medications showed that carvedilol at high doses increased tissue $\mathrm{H}_{2} \mathrm{~S}$ level in the heart (by 75\%) 
kidney and liver however decreased in the brain of SJL female mice. Digoxin increased $\mathrm{H}_{2} \mathrm{~S}$ in all investigated organs (BALB/c male mice), especially in the heart (by 22\%) while amlodipine tended to decrease it in all examined organs (CBA mice) [69-71]. Overall these findings further implicate the $\mathrm{H}_{2} \mathrm{~S}$ in the nociception, $\mathrm{NO}$ and $\mathrm{CO}$ metabolism, ACE regulation, and cardioprotection, however, with little indication as to the molecular mechanisms downstream of $\mathrm{H}_{2} \mathrm{~S}$. Studies by Calvert et al. have shown that $\mathrm{H}_{2} \mathrm{~S}$ is a potent inducer of Nrf2 which governs a group of antioxidant and drug metabolizing genes [72]. How Nrf2 activation relates to findings by Wilinski et al. awaits further investigation.

Above mentioned gaseous compounds have been proposed as therapeutic agents, e.g. the administration of $\mathrm{H}_{2} \mathrm{~S}$ donors for renal diseases, associated with deficiency of endogenous $\mathrm{H}_{2} \mathrm{~S}$ [73]. Since $\mathrm{NO}$ can increase red blood cell deformability, its donors have been proposed as agents improving blood fluidity [74]. However any carbon monoxide treatment due to a risk of toxicity would need to be closely monitored [75].

\section{Volatile anesthetics in basic and clinical research}

Polish researchers made valuable contributions to pros and cons discussion over advantages of intravenous vs. inhalational anesthesia. They increased overall number of clinical cases examined in the world literature in order to establish superiority of anesthetic methods in this regard. The achievement worth emphasizing was also to demonstrate the involvement of endogenous opioids in the mechanisms of volatile anesthesia/analgesia. The work by Polish researchers on EEG pattern analysis furthered the understanding of mechanisms behind inhalational anesthesia. Time will tell whether new algorithms of EEG analysis elaborated in Poland will be broadly implemented for anesthesiological procedures.

The Polish researchers were also amongst the first to show advantages of newer halogenated gases over older agents e.g. they showed that isoflurane has lower genotoxicity than halothane towards peripheral blood lymphocytes [76]. Other authors demonstrated that compared to isoflurane, enflurane produces stronger alterations in the activities of brain enzymes responsible for catabolic processes, and the rates of exchange and transport of energetic substrates in the striatum and hypothalamus in the rabbit brain. Therefore, the authors suggested that enflurane offers lower safety than isoflurane [77]. Polish authors also conducted the comparisons between different 3rd generation agents e.g. sevoflurane and isoflurane (0.6-1.5 MAC) for cardiopulmonary bypass, by assessing total usage of phenylephrin administered against drops in arterial pressure, which together with hemodynamics data revealed no difference in major parameters including cardiopulmonary bypass and aortic cross clamp times, ejection fraction, temperature, and EuroSCORE indexes. [78]. Researchers at Medical University of Lublin found that desflurane increased peripheral perfusion in elective gynecologic surgery patients as determined with perfusion index [79]. The classic advantage of desflurane, rapid emergence from anesthesia, was studied in obese patients by Dr. Gaszynski who found faster recovery and faster (16,3 vs $22,4 \mathrm{~min}$ ) reaching 10 points on the Aldrete scale by those patients (47 individuals with BMI $>40 \mathrm{~kg} / \mathrm{m} 2$; ASA 2) anesthetized with desflurane for gastric banding, compared with sevoflurane [80]. Interestingly, sevoflurane anesthesia can reduce rocuronium requirement as sevoflurane potentiates neuromuscular block [81]. Similarly sevoflurane decreased the required dose of muscle relaxant in laparoscopic gastric banding [82].

Other comparisons were made between halogenated anesthetics such as isoflurane and injectable anesthetics e.g. propofol. Both isoflurane and propofol provided effective clinical anesthesia and could be safely used for short gynecological surgery. Times to eye opening, to recovery of spontaneous breathing, and to extubation were equivalent between inhalation and injection anesthesia groups [83]. Similarly, single-breath vital capacity rapid induction with $8 \%$ sevoflurane followed by $1.5 \%$ sevoflurane with $\mathrm{N}_{2} \mathrm{O}$ was as effective as propofol for short gynecological procedures [84]. Desflurane and propofol combined with thoracic epidural anesthesia showed similar effectiveness and safety profile in one lung ventilation upon lobectomy [85]. As demonstrated in patients with embolization of cerebral haemangiomas or arteriovenous malformations, sevoflurane provides safe and stable anesthesia for interventional neuroradiological procedures compared to propofol/fentanyl anesthesia [86].

However quite a few Polish studies investigated the very mechanism of anesthetic action of halogenated gases both on basic science and clinical grounds where the understanding is far from complete. These studies showed that once postulated theory of anesthesia, referring to endogenous opioid peptides may appear plausible as leu-enkephalin has been found increased in hypothalamus, hippocampus, mesencephalon and lumbar segment of spinal cord in isoflurane anesthetized rabbits. However both leu-enkephalin and met-enkephalin decreased in the cervical segment while met-enkephalin content dropped in thoracic part of the spinal cord. Unlike isoflurane halothane decreased leu-enkephalin content in the hypothalamus, while increased in the hippocampus. Methionineenkephalin levels however increased upon halothane and persisted at least $1 \mathrm{hr}$ after anesthesia has been ceased $[87,88]$.

Polish researchers actively participate in devising new analysis modes for investigating mechanisms and safety of volatile anesthetics. BIS monitoring is commonly used for studies aimed at optimization of anesthesia for particular 
clinical procedures. With this approach researchers found e.g. that desflurane allows to wake faster, when compared with sevoflurane and isoflurane, after lumbar laminotomy in 60 adult patients [89]. One Silesian group studied EEG propagation under sevoflurane using directed transfer function method. Indeed the assessment of propagation directions of EEG signals between channels may upgrade analysis of spatial distribution of EEG activity [90]. Furthermore, quantitative analysis of EEG for transition from consciousness to unconsciousness for isoflurane, sevoflurane and desflurane revealed relative powers of particular EEG waves [91]. As to desflurane, researchers further elaborated new methods to detect sharp wave and slow wave components of the EEG pattern to investigate of possible side effects of this anesthetic gas in the clinical settings [92].

Notably the impact of inhalational anesthetic agents on body systems/organs has been studied in Poland as well. Studies have indicated that sevoflurane low flow (0.8-1 L min-1) air-oxygen-sevoflurane (1-3 MAC) does not increase nephrotoxicity of chemotherapeutic agents [93]. It also turned out that both isoflurane and halothane could affect airway transepithelial potential difference in the isolated rabbit tracheal wall, which suggests depressing airway clearance. Notably, isoflurane distinctly less affected the depolarization component while the reaction to both gases was fully reversible [94]. In the meantime studies directed at risk of toxicity turned out quite favorable for sevoflurane, which did not induce any increase in DNA migration in blood lymphocytes proliferating in vitro, in contrast to halothane and isoflurane [95]. However sevoflurane's impact on liver function has been reconfirmed. Sevoflurane was found to be a more potent microsome liver cytochrome b5 inhibitor than desflurane [96].

Then the mechanisms of brain and heart protection with volatile anesthetic agents gained Polish researchers' interest as well. As stressed in one original paper by Baranowska et al. neurological complication during heart surgery relate to long duration of ventilation, prolonged crossclamping and $\mathrm{CPB}$ while low CPP, history of atrial fibrillation or stroke as well as advanced age, hence the need for clinically effective preconditioning procedures [97]. Both isoflurane and sevoflurane could reduce biochemical markers of brain injury including MMP-9, GFAP and S-100 $\beta$, and ameliorated disturbed arteriovenous magnesium concentration differences in patients after CABG, as compared to intravenous anesthesia [98,99]. Studies conducted in USA and elsewhere have shown multiple mechanisms for brain protection with isoflurane including activation of ATP-regulated potassium channels, upregulation of NOS and PI3K-AKT and reduced excitotoxic stress [100]. Recent studies have indicated that major mechanism of isoflurane-induced neuroprotection leads through sphingosine-1-phosphate/phosphatidylinositol-3kinase/Akt pathway [101].

In addition, Polish experimental studies have shown that sevoflurane inhibits synthesis and release of excitatory neurotransmitters, including glutamate, and inhibits activation of microglia and astrocytes responsible for the occurrence of inflammation after ICH $[102,103]$.

Some Polish researchers have examined volatile anesthesia against cardiac injury as well. One study has found that anesthetic preconditioning with sevoflurane (20 minutes of sevoflurane $2 \mathrm{vol} \%$ inhalation at $10 \mathrm{~min}$ prior to CABG under $\mathrm{CPB}$ ) acutely activates ROS generation in coronary sinus blood, but then decreases blood levels of interleukin-6 at six hours after surgery [104].

Particularly interesting direction in research is formed by nitrous oxide studies. $\mathrm{N}_{2} \mathrm{O}$ is commonly used to decrease anesthetic requirements of halogenated gases allowing to study different anesthetic agents at lower concentrations. Upon such studies Polish researchers found that children anesthetized with $\mathrm{N}_{2} \mathrm{O} / \mathrm{O}_{2}$-fentanyl had higher mivacurium requirement than those in halogenated anesthetics $/ \mathrm{N}_{2} \mathrm{O} / \mathrm{O}_{2}$ group, which may carry implications for residual muscle weakness [105]. The duration of intubating dose and spontaneous recovery of neuromuscular transmission were significantly prolonged by halogenated gases as compared to $\mathrm{N}_{2} \mathrm{O} / \mathrm{O}_{2}$-fentanyl anesthesia [106].

Also, encouraging results were reported for nitrous oxide in sedation. Some Polish authors postulated that nitrous oxide should be wider used for sedation in oral surgery [107]. One study has found however that despite good outcomes of nitrous oxide sedation for dental treatment 6 out of 20 children refused to breathe through the mask under any circumstances and had to be subjected to general anesthesia [108]. Definitely, caution should be advocated for the use of $\mathrm{N}_{2} \mathrm{O}$ or halogenated anesthetics in sedation especially in children as there is a substantial body of data pointing towards possible neurodegenerative effects of those in case of prolonged exposure [109].

\section{Noble gas in Polish medical research}

Amongst noble gases helium has been studied quite extensively in the intensive care and diving medicine in Poland. Polish scientists contributed to establishing usefulness of breathing helium for diving and treatment of diving accidents, and used against neonatal respiratory distress as well. These series of diving cases are of unique value, especially diving accidents cannot be easily replicated. Helium neonatal studies also have a great importance for clinical practice. These have proved that medical gas research conducted in Poland can advance to clinical trials registered with NIH.

Helium in diver's breathing gas allows to decrease partial pressure of nitrogen thus diminishing unfavorable effects of the latter, helium also allows to decrease the 
work of breathing. In addition heliox, which is a mix of helium and oxygen, has been proposed to counter unfavorable hematological consequences of diving, amongst which loss of circulating platelets appears most common [110]. With this regard, breathing trimix (O2 - 18.5\%, $\mathrm{N} 2-44 \%, \mathrm{He}-37.5 \%)$ prevented reduction in the number of platelets and loss of coagulation factor XII in male professional divers subjected to $0.7 \mathrm{MPa}$ exposure (35 min. plateau). Since solubility and diffusion coefficients of helium are relatively low there will be faster release of dissolved gas during decompression and reduced formation of gas bubbles in diver's blood, hence reduced number of platelet aggregates [111].

Breathing gas mix with helium has been investigated clinically as well. As reviewed by Polish authors, heliox, possess suitable properties as a carrier of aerosol therapy and a breathing mix upon mechanical ventilation. These include facilitation of laminar flow and reduction of airway resistance. Therefore it has been postulated that patients with severe bronchospastic diseases may experience the greatest benefits of breathing heliox [112]. Others have postulated that heliox containing $20 \%$ oxygen and $80 \%$ helium seems to be a very promising treatment in the management of the acute phase of severe respiratory disturbances in the newborn [113]. A group of researchers at Poznań University of Medical Sciences administered heliox through mechanical ventilation in the meconium aspiration syndrome in neonates. This particular study was a subject to a clinical trial registered at http:// clinicaltrials.gov. Recently the authors have reported that there was a significant increase in the $\mathrm{PaO}(2) \mathrm{FiO}(2)$ ratio during heliox ventilation in their clinical setting [114]. As to moleculaer mechanisms helium imparts influence on molecular machinery of the cells within lungs, the immune system, and the blood, besides improving work of breathing. At least part of therapeutic effects of helium may be ascribed to activation of mitochondrial ATP regulated potassium channels for cell protection [115].

\section{On some gaseous compounds for ultrasonography}

It is an important contribution of Polish researchers to prove safety of ultrasound sulfur hexafluoride microbubble contrast agent (SonoVue) with respect to hematologic system. Furthermore, based on extensive research Polish authors postulated that contrast enhanced ultrasound may become a method of choice for determination of character of liver lesion.

Micro bubble contrast agents, formulated with encapsulated gaseous compounds, have received researchers attention for the studies of contrast enhanced ultrasound (CEUS). In the beginning ultrasound contrast agents utilized air microbubbles (generated via sonication) or galactose microparticles [116]. Later on, many studies have investigated the ultrasound second-generation contrast agents such as SonoVue. This particular agent is formed by stabilized microbubbles of sulfur hexafluoride $\left(\mathrm{SF}_{6}\right)$ gas and exhibits an outstanding safety profile [117]. Bubbles of $\mathrm{SF}_{6}$ are extremely small; the bubble diameter in SonoVue averages $2.5 \mu \mathrm{l}$, which allows to minimize total volume of injected gas [118]. Polish researchers elaborated on SonoVue safety by demonstrating with electrophoretic mobility techniques that SonoVue did not produce large changes with respect to surface charge density of red blood cell membranes [119]. Based on the results obtained in Polish academic hospitals contrast enhanced ultrasound has been postulated as a modality of choice in the diagnostics and differentiation of benign focal liver lesions [120]. Although being less accurate than histological assessment CEUS still allows to predict malignant character of renal lesions [121]. CEUS has been also compared to CT with respect to accuracy of imaging. Contrast-enhanced ultrasonography may be considered an alternative technique to CTA in monitoring patients after abdominal aortic aneurysm repair [122]. There was a high accordance between CEUS and CT in the diagnostics of metastatic liver lesions [123]. In cases of liver hemangiomas CEUS managed to approximate CT accuracy, however specificity and negative predictive value appeared lower [124].

\section{Concluding remarks and prospects of researching medical gases in Poland}

In summary research of medical gas in Poland is in large part directed at testing novel clinical applications of medical gases. However thorough investigations with the use of molecular biology and genetics techniques, including omics approach, are developing as well. Undeniably, in order to progress, research of medical gas needs to be financed from major dedicated funds. This appears necessary, especially to assure diversity in translational research, but also to integrate medical gas research with stem cell and molecular biology investigations. Also, to further medical gas research in Poland, international collaborations with leading medical gas research centers are warranted, for mutual benefits.

\section{Abbreviations}

ACE: Angiotensin-converting-enzyme; ATA: Atmosphere absolute; BIS: Bispectral index; CABG: Coronary artery bypass grafting; CEUS: Contrast enhanced ultrasound; CO: Carbon monoxide; CPB: Cardiopulmonary bypass; CPP: Cerebral perfusion pressure; $\mathrm{CT}$ : Computed tomography; $\mathrm{FiO}_{2}$ : Fraction of inspired oxygen; GFAP: Glial fibrillary acidic protein; GSH: Glutathione; $\mathrm{H}_{2} \mathrm{O}_{2}$ : Hydrogen peroxide; $\mathrm{H}_{2} \mathrm{~S}$ : Hydrogen sulfide; HBA: Hyperbaric air; HBO: Hyperbaric oxygen; $\mathrm{HI}$ : Hypoxia-ischemia; HIF-1a: Hypoxia inducible factor 1a; HV1: Herpes virus type l; ICH: Intracerebral hemorrhage; ICP: Intracranial pressure;

ICV: Intracerebroventricularly; LDL: Low-density lipoprotein; LOPS: Lipid oxidation products; IFN-ץ: Interferon Y; IL-2: Interleukin 2; MAC: Minimum alveolar concentration; MMP-9: Matrix metalloproteinase-9; MHC: Major histocompatibility complex; $\mathrm{N}_{2} \mathrm{O}$ : Nitrous oxide; NF-kB: Nuclear factor kappa-light-chain-enhancer of activated B cells; NO: Nitric oxide; Nrf2: Nuclear factor E2-related factor;

$\mathrm{PaO}_{2}$ : Partial pressure of oxygen in the plasma of arterial blood; Ppm: Parts per million; ROS: Reactive oxygen species; $\mathrm{SF}_{6}$ : Sulfur hexafluoride; SOD: Superoxide dismutase; VEGF: Vascular endothelial growth factor. 


\section{Competing interests}

The authors declare that they have no competing interests.

\section{Authors' contributions}

RPO: drafted the manuscript. EP: was involved in drafting the manuscript. Both authors read and approved the final manuscript.

Received: 22 March 2013 Accepted: 1 August 2013

Published: 2 August 2013

\section{References}

1. Harris JC: Alchemist Sendivogius and Sigismund III Vasa. Arch Gen Psychiatry 2011, 68:771-772.

2. Hrynkiewicz A, Szytuła A: Centennial of air components liquefaction Post Fiz 1985, 36:41.

3. Wick JY: Long-term oxygen therapy: battling breathlessness. Consult Pharm 2012, 27:826-830. 833-826.

4. Macaulay D: Liquid nitrogen for cryotherapy. Br J Gen Pract 2012, 62:572

5. Felczak-Korzybska I, Nahorski WL: Institute of Maritime and Tropical Medicine in Gdynia on the 70(th) anniversary of foundation (1939-2009) - history, staff, achievements. Int Marit Health 2009, 60:71-74.

6. Sukiennik A, Kruczek P, Pietrzyk JJ, Wajs W, Tadeusiewicz R, Pisarkiewicz T: A continuous measurement method for blood gases prediction using newral network. PAK 1999, 7:24-29.

7. Lasoń W, Bogdał P, Walecki P, Pyrczak W: The simulation model of oxygen gas exchange. Bio Algorithm Med Syst 2005, 1:233-236.

8. Pańkowska E, Szypowska A, Staniszewska K: Tissue oxygen availability in children and adolescents with type 1 diabetes mellitus: risk factors for tissue hypoxia. Diabetol Dośw Klini 2007, 7:276-281.

9. From S, Lewandowski K, Pacholska-Pytlakowska M: Recent indications for home oxygen therapy. Pol Merkuriusz Lek 2011, 31:368-371.

10. Tołłoczko J, Sonczyk-Zapała A, Hautz W, Puskarz-Gąsowska J, Kornacka MK. Maximal oxygen concentration in the respiratory mixture and retinopathy of prematurity. Perinatol Neonatol i Ginekol 2011, 4:149-153.

11. Lauterbach R, Musialik-Świetlińska E, Świetliński J, Pawlik D, Bober K: Use of oxygen and air in resuscitation of the newborn after birth, current views and recommendations. Med Wieku Rozwoj 2008, 12:857-861.

12. Dolatkowski A: Development of hyperbaric oxygen therapy. Ann Acad Med Stetin 1974, 10:241-246.

13. Krzyżak J: Polish diving and hyperbar ic medicine publications. Pol Hyperb Res 2007, 19:47-52.

14. Kawecki M, Sieroń A, Glik J, Nowak M, Szymańska B, Knefel G: The role of Hyperbaric Oxygen Therapy (HBO) in surgical treatment of trophic ulcerations, caused by persistant venous insufficiency. Med Rodz 2006, 3:150-155

15. Cholewka A, Knefel G, Stanek A, Kawecki M, Nowak M, Sieroń A, Drzazga Z: Thermal imaging and TC oximetry measurements of hyperbaric oxygen therapy (HBO) effects on trophic ulceration of the crura. J Therm Anal Calorim 2012, 108:25-31.

16. Knefel G, Kawecki M, Szymańska B, Nowak M, Glik J, Cieślar G, Sieroń A: Hyperbaric oxygen therapy as a supplement to surgical treatment of diabetic foot syndrome. Acta Bio-Opt Inform Med 2008, 14:47-50.

17. Kawecki M, Knefel G, Szymańska B, Nowak M, Sieroń A: Hyperbaric Oxygen Treatment in Burn Treatment Center, Siemianowice Slaskie. Own Experience. Baln Pol 2006, 4:211-219.

18. Baranowska J, Machała W, Chmiela K: Hyperbaric oxygen therapy in the treatment of Fournier's gangrene; case raport. Zakażenia 2010, 10:77-83.

19. Knefel G, Kawecki M, Szumańska B, Nowak M, Glik J, Cieślar G, Sieroń A: Application of hyperbaric oxygen therapy (HBO) in the complex treatment of electric burns. Acta Bio-Opt Inform Med 2008, 14:103-106.

20. Siondalski P, Keita L, Sicko Z, Zelechowski P, Jaworski L, Rogowski J: Surgical treatment and adjunct hyperbaric therapy to improve healing of wound infection complications after sterno-mediastinitis. Pneumon Alergol Pol 2003, 71:12-16.

21. Narozny W, Kuczkowski J, Stankiewicz C, Kot J, Mikaszewski B, Przewozny T: Value of hyperbaric oxygen in bacterial and fungal malignant external otitis treatment. Eur Arch Otorhinolaryngol 2006, 263:680-684

22. Narożny W, Kot J, Kuczkowski J, Sićko Z, Stankiewicz C: Hyperbaric oxygen therapy in children with sudden sensorineural hearing loss. Otorynolaryngologia 2010, 9:30-35.
23. Narozny W, Sicko Z, Kuczkowski J, Stankiewicz C, Przewozny T: Usefulness of hyperbaric oxygen therapy in patients with sensorineural acute and chronic tinnitus. Int Congr 2003, 1240:277-286.

24. Narozny W, Sicko Z, Kot J, Stankiewicz C, Przewozny T, Kuczkowski J: Hyperbaric oxygen therapy in the treatment of complications of irradiation in head and neck area. Undersea Hyperb Med 2005, 32:103-110.

25. Jedrusik-Pawlowska M, Niedzielska I, Bogucki R, Kajewski B: Effectiveness of hyperbaric oxygen therapy in mandibular osteoradionecrosis shown by thermography monitoring. Med Sci Monit 2010, 16:MT1-MT8.

26. Guo MF, Yu JZ, Ma CG: Mechanisms related to neuron injury and death in cerebral hypoxic ischaemia. Folia Neuropathol 2011, 49:78-87.

27. Malek M, Duszczyk M, Zyszkowski M, Ziembowicz A, Salinska E: Hyperbaric oxygen and hyperbaric air treatment result in comparable neuronal death reduction and improved behavioral outcome after transient forebrain ischemia in the gerbil. Exp Brain Res 2013, 224:1-14.

28. Gamdzyk M, Ziembowicz A, Salinska E: Hypobaric hypoxia and hyperbaric treatment prevent neuronal damage and affect antioxidant activity in neonatal hypoxia-ischemia rat model. Acta Neurobiol Exp 2013. In Press.

29. Bialoszewski D, Kowalewski M: Superficially, longer, intermittent ozone theraphy in the treatment of the chronic, infected wounds. Ortop Traumatol Rehabil 2003, 5:652-658.

30. Bialoszewski D: The use of the intraooperative ozone - theraphy as prophylaxis of infections in surgery of locomotor system with special regard to total hip plasty - a preliminary study. Ortop Traumatol Rehabil 2003, 5:781-786

31. Adamczyk P, Szmurło W, Ponikowska I, Sosnowsk S, Mindykowski R: Clinical evaluation of own method of treatment for decubitus ulcers with oxygen-ozone mix - preliminary results. Baln Pol 2001, 43:58-65.

32. Sroczynski J, Antoszewski Z, Matyszczyk B, Krupa G, Rudzki H, Zbronska H, Skowron J: Clinical assessment of treatment results for atherosclerotic ischemia of the lower extremities with intraarterial ozone injections. Pol Tyg Lek 1992, 47:964-966.

33. Tylicki L, Biedunkiewicz B, Nieweglowski T, Chamienia A, Slizien AD, Luty J, Lysiak-Szydlowska W, Rutkowski B: Ozonated autohemotherapy in patients on maintenance hemodialysis: influence on lipid profile and endothelium. Artif Organs 2004, 28:234-237.

34. Tafil-Klawe M, Wozniak A, Drewa T, Ponikowska I, Drewa J, Drewa G, Wlodarczyk K, Olszewska D, Klawe J, Kozlowska R: Ozone therapy and the activity of selected lysosomal enzymes in blood serum of patients with lower limb ischaemia associated with obliterative atheromatosis. Med Sci Monit 2002, 8:CR520-525.

35. Kujawa J, Szmagaj-Piotrowska J, Gworys K, Leszczyńska A, Dudek K, Chrzanowska M, Pieszyńsk I, Gworys P, Maziarz Z, Gadzicki M, Tryniszewski $W$ : The influence of the selected methods of hydrotherapy and kinesitherapy on the knee joint physical condition and pain in patients with gonarthrosis. Prz Med Uniw Rzesz Inst Leków 2011, 1:40-52.

36. Iwanek P: Biological grounds of the effect of ozone on oral flora. Ann Acad Med Stetin 2007, 3(Suppl 53):41-44.

37. Półjanowska M, Kędzia A, Kochańska B: The susceptibility of microaerophilic bacteria isolated from the oral cavity to ozone. In vitro study. Ann Acad Med Stetin 2007, 53:114-118.

38. Wilczynska-Borawska M, Leszczynska K, Nowosielski C, Stokowska W: Ozone in dentistry: microbiological effects of gas action depending on the method and the time of application using the ozonytron device. Experimental study. Ann Acad Med Stetin 2011, 57:99-103.

39. Olczak-Kowalczyk D, Matosek A, Adamczyk Ł, Kurenko-Deptuch M: Ozonotherapy impact for gingival pocket's microbiological status in children with granulomatous disease. Nowa Stomatol 2010, 1:25-30.

40. Lempe B, Markunina M: Ozonetheraphy in the endodontic treatment of chronic periapical inflammation - clinical cases. Dent Forum 2009, 37:89-93.

41. Turska-Szybka A, Sobczak M, Remiszewski A, Stańczak-Sionek D, Boguszewska-Guttenbaum $\mathrm{H}$ : The treatment of premolar teeth' primary occlusal pit and fissure caries using ozone-therapy. Nowa Stomatol 2007, 1:13-16.

42. Chałas R, Bachanek T, Wójcik-Chęcińska I, Zamościńska J: Using of ozone in dentin hypersensitivity. Preliminary report. Dent Forum 2011, 39:47-51.

43. Bartkowiak-Fludra E, Jasińska-Stępniak A, Gogolewski M, Irena P: Studies on the effect of ozonotherapy on blood serum a-tocopherol level in patients with atherosclerotic ischemia of lower extremities. New Med 2007, 1:10-14 
44. Ciborowski M, Lipska A, Godzien J, Ferrarini A, Korsak J, Radziwon P, Tomasiak M, Barbas C: Combination of LC-MS- and GC-MS-based Metabolomics to Study the Effect of Ozonated Autohemotherapy on Human Blood. J Proteome Res 2012, 11:6231-6241.

45. Milnerowicz HMJ: Metallothionein-biomarker of Cd exposition. Part II: Immunohistochemical localization of metallothionein in tissues of rats intoxicated with cadmium acetate and subjected to peritoneal oxygenozone injections. Toxicol Lett 1998, 1(Suppl 95):125.

46. Bocci VA: Scientific and medical aspects of ozone therapy. State of the art. Arch Med Res 2006, 37:425-435.

47. Żuryńska M: Nitric oxide therapy as professional life saving activity. Prz Chir Dziec 2008, 3:269-272.

48. Knapik P, Zembala M, Nadziakiewicz P, Glanc W, Knapik M, Saucha W: Effects of inhaled nitric oxide on the cardiovascular system in patients with mitral valve disease and pulmonary hypertension. Kardiol Pol 2001 55:297-300

49. Knapik P, Grzybowski A, Wojtalik M, Białkowski J, Skalski J, Nadziakiewicz P, Saucha W, Banaszak B: Nitric oxide for the pulmonary hypertensive crisis after open-heart surgery. Anestezjol Intens Ter 2001, 2:73-77.

50. Jachec WP, Wojciechowska CA, Gala A, Tomasik A, Kawecki D, KrzemienWolska K, Nowalany-Kozielska E: Positive pulmonary hypertension reversibility test with nitric oxide but not with nitroprusside indicates better prognosis in patients with dilated cardiomyopathy and pulmonary hypertension. Eur J Heart Fail Suppl 2012, 11(S1):S273.

51. SK S, Pawlik MW, Brzozowski T, Konturek PC, Sliwowski Z, Pawlik WW, Konturek SJ: Nitric oxide (NO)-releasing aspirin and (NO) donors in protection of gastric mucosa against stress. J Physiol Pharmacol 2008, 2(Suppl 59):103-115

52. Brzozowski T, Konturek PC, Konturek SJ, Pajdo R, Drozdowicz D, Kwiecien S, Hahn EG: Acceleration of ulcer healing by cholecystokinin (CCK): role of CCK-A receptors, somatostatin, nitric oxide and sensory nerves. Regul Pept 1999, 82:19-33.

53. Brzozowski T, Konturek PC, Pajdo R, Drozdowicz D, Pawlik M, Ptak A, Konturek SJ, Hahn EG: Involvement of nitric oxide (NO) in the mechanism of gastric preconditioning induced by short ischemia. Inflammopharmacology 2002, 10:449-460.

54. Weerateerangkul P, Chattipakorn S, Chattipakorn N: Roles of the nitric oxide signaling pathway in cardiac ischemic preconditioning against myocardial ischemia-reperfusion injury. Med Sci Monit 2011, 17:RA44-52.

55. Talarek S, Fidecka S: Role of nitric oxide in benzodiazepines-induced antinociception in mice. Pol J Pharmacol 2002, 54:27-34.

56. Przesmycki K, Dzieciuch JA, Czuczwar SJ, Kleinrok Z: Nitric oxide modulates spinal antinociceptive effect of clonidine but not that of baclofen in the formalin test in rats. Eur Neuropsychopharmacol 1999, 9:115-121.

57. Guratowska M, Schmager J, Groszek B, Pach D, Szurkowska M: Genotoxic effect of carbon monoxide estimated by the sister-chromatide-exchange test. Prz Lek 2006, 63:428-432.

58. Bojakowski K, Gaciong Z, Grochowiecki T, Szmidt J: Carbon monoxide may reduce ischemia reperfusion injury: a case report of complicated kidney transplantation from a carbon monoxide poisoned donor. Transplant Proc 2007, 39:2928-2929.

59. Chen B, Guo L, Fan C, Bolisetty S, Joseph R, Wright MM, Agarwal A, George JF: Carbon monoxide rescues heme oxygenase-1-deficient mice from arterial thrombosis in allogeneic aortic transplantation. Am J Pathol 2009, 175:422-429.

60. Kramkowski K, Leszczynska A, Mogielnicki A, Chlopicki S, Fedorowicz A Grochal E, Mann B, Brzoska T, Urano T, Motterlini R, Buczko W: Antithrombotic properties of water-soluble carbon monoxide-releasing molecules. Arterioscler Thromb Vasc Biol 2012, 32:2149-2157.

61. Amano MT, Camara NO: The immunomodulatory role of carbon monoxide during transplantation. Med Gas Res 2013, 3:1.

62. Nicholson CK, Calvert JW: Hydrogen sulfide and ischemia-reperfusion injury. Pharmacol Res 2010, 62:289-297.

63. Martelli A, Testai L, Breschi MC, Blandizzi C, Virdis A, Taddei S, Calderone V: Hydrogen sulphide: novel opportunity for drug discovery. Med Res Rev 2012, 32:1093-1130.

64. Wilinski B, Wilinski J, Somogyi E, Goralska M, Piotrowska J: Ramipril affects hydrogen sulfide generation in mouse liver and kidney. Folia Biol 2010, 58:177-180

65. Wiliński B, Wiliński J, Somogyi E, Piotrowska J, Opoka W: Vitamin D3 (Cholecalciferol) Boosts Hydrogen Sulfide Tissue Concentrations in Heart and other Mouse Organs. Folia Biol 2012, 60:243-247.
66. Bilska A, Iciek M, Kwiecien I, Kaniecki K, Paliborek M, Somogyi E, Piotrowska J. Wilinski B, Goralska M, Srebro Z, Wlodek L: Effects of aspirin on the levels of hydrogen sulfide and sulfane sulfur in mouse tissues. Pharmacol Rep 2010, 62:304-310.

67. Wilinski B, Wilinski J, Somogyi E, Goralska M, Piotrowska J: Paracetamol (acetaminophen) decreases hydrogen sulfide tissue concentration in brain but increases it in the heart, liver and kidney in mice. Folia Biol 2011, 59:41-44.

68. Wilinski B, Wilinski J, Somogyi E, Piotrowska J, Goralska M: Atorvastatin affects the tissue concentration of hydrogen sulfide in mouse kidneys and other organs. Pharmacol Rep 2011, 63:184-188.

69. Wilinski B, Wilinski J, Somogyi E, Piotrowska J, Goralska M: Amlodipine affects endogenous hydrogen sulfide tissue concentrations in different mouse organs. Folia Med Cracov 2011, 51:29-35.

70. Wilinski B, Wilinski J, Somogyi E, Piotrowska J, Goralska M: Digoxin increases hydrogen sulfide concentrations in brain, heart and kidney tissues in mice. Pharmacol Rep 2011, 63:1243-1247.

71. Wilinski B, Wilinski J, Somogyi E, Piotrowska J, Goralska M, Macura B: Carvedilol induces endogenous hydrogen sulfide tissue concentration changes in various mouse organs. Folia Biol 2011, 59:151-155.

72. Calvert JW, Jha S, Gundewar S, Elrod JW, Ramachandran A, Pattillo CB, Kevi CG, Lefer DJ: Hydrogen sulfide mediates cardioprotection through Nrf2 signaling. Circ Res 2009, 105:365-374.

73. Beltowski J: Hypoxia in the renal medulla: implications for hydrogen sulfide signaling. J Pharmacol Exp Ther 2010, 334:358-363.

74. Starzyk D, Korbut R, Gryglewski RJ: Effects of nitric oxide and prostacyclin on deformability and aggregability of red blood cells of rats ex vivo and in vitro. J Physiol Pharmacol 1999, 50:629-637.

75. Mahan VL: Neuroprotective, neurotherapeutic, and neurometabolic effects of carbon monoxide. Med Gas Res 2012, 2:32.

76. Jaloszynski P, Kujawski M, Wasowicz M, Szulc R, Szyfter K: Genotoxicity of inhalation anesthetics halothane and isoflurane in human lymphocytes studied in vitro using the comet assay. Mutat Res 1999, 439:199-206.

77. Kmieciak-Kolada K, Chmielnicki Z, Was M, Huzarska M, Obuchowicz E, Spiewak Z, Kaminski M, Plewka A, Dyaczynska-Herman A, Herman ZS: Effect of enflurane on selected neuropeptides and marker enzymes in rabbit brain. Pol J Pharmacol 1998, 50:315-325

78. Nadziakiewicz P, Werner M, Saucha W, Knapik P: Comparison of haemodynamic effects of sevoflurane and isoflurane during cardiopulmonary bypass. Eur J Anaesthesio/ Supp/ 2003, 29:1-55.

79. Fijałkowska A, Kowalczyk M: Alterations of peripheral blood flow upon general anesthsia with desflurane. Anestezjol Intens Ter 2010, 42:11-14.

80. Gaszyński T, Jakubiak J: A comparison study of recovery profile after general anaesthesia with desflurane or sevoflurane in morbidly obese patients. Anest Ratow 2011, 5:40-44.

81. Woloszczuk-Gebicka B, Wyska E, Grabowski T: Sevoflurane increases fade of neuromuscular response to TOF stimulation following rocuronium administration in children. A PK/PD analysis. Paediatr Anaesth 2007, 17:637-646.

82. Gaszyński TM, Machała W, Szewczyk TB, Gaszyński WP: Sevoflurane allows for decreasing the total dose of muscle relaxant for laparoscopic gastric banding. Clin Exp Med Lett 2007, 48:41-43

83. Florek AN A: A comparative assessment of desflurane vs. propofol for gynecological laparoscopic surgery. Anestezjol Intens Ter 2004, 1:24-27.

84. Ogonowska-Kobusiewicz M, Wrońska-Sewruk A, Kowalczyk M, Tomaszewski J: Propofol vs sevoflurane anaesthesia for short gynaecological procedures. Anestezjol Intens Ter 2005, 2:87-91.

85. Werszner M, Misiołek H, Karpe J, Rutkowska K: The haemodynamic and respiratory effects of propofol and desflurane anaesthesia for lung surgery with one-lung ventilation: A comparative study. Kardiochirurgia : Torakochirurgia Polska 2010, 7:298-303.

86. Czechowski M, Karpel E, Was M, Duda I, Grzybowska K, Seifert B: Anaesthesia for interventional neuroradiology. Anestezjol Intens Ter 2006, 38:14-17.

87. Chmielnicki Z, Kmieciak-Kolada K, Spiewak Z, Kotnis D, Dyaczynska-Herman A, Herman ZS: Influence of halothane on the level of enkephalins in discrete brain areas of rabbits. Pol J Pharmacol 1995, 47:37-41.

88. Chmielnicki Z, Was M, Kmieciak-Kolada K, Huzarska M, Spiewak Z, Pawlowski J, Kaminski M, Dyaczynska-Herman A, Herman ZS: Influence of isoflurane on enkephalin levels and on some indicatory enzymes in the central nervous system of rabbits. Pol J Pharmacol 1997, 49:97-106. 
89. Skaja D, Graff M, Karwacki Z, Zieliński P, Kowiański P, Słoniewski P: BIS monitoring during volatile anaesthesia for lumbar laminotomy. Anestezjol Intens Ter 2006, 2:72-75.

90. Olejarczyk E, Kaminski M, Marciniak R, Byrczek T, Stasiowski M, Jalowiecki P, Sobieszek A, Zmyslowski W: Estimation of the propagation direction and spectral properties of the EEG signals registered during sevoflurane anaesthesia using Directed Transfer Function method. Pol J Med Phys Eng 2011, 17:95-104.

91. Olejarczyk E, Sobieszek A, Rudner R, Marciniak R, Wartak M, Stasiowski M, Jałowiecki P: Spectral Analysis of the EEG-signal Registered during Anaesthesia Induced by Propofol and Maintained by Fluorinated Inhalation Anaesthetics. Biocybernetics Biomed Eng 2010, 30:55-70.

92. Olejarczyk E, Jozwik A, Zmyslowski W, Sobieszek A, Marciniak R, Byrczek T, Jalowiecki P, Bem T: Automatic detection and analysis of the EEG sharp wave-slow wave patterns evoked by fluorinated inhalation anesthetics. Clin Neurophysiol 2012, 123:1512-1522.

93. Wujtewicz M, Sawicka W, Wenski W, Marciniak A, Wujtewicz MA, Stepnowski P, Twardowski P, Dylczyk-Sommer A, Owczuk R: The influence of low flow anaesthesia on renal function in cancer patients previously treated with nephrotoxic chemotherapeutic agents. Anaesthesiol Intensive Ther 2012, 44:71-75.

94. Smuszkiewicz P, Drobnik L, Mieszkowski J, Konikowski A, Holynska I, Kaczorowski P, Tyrakowski T: Comparison of the influence of halothane and isoflurane on airway transepithelial potential difference. Pharmacol Rep 2006, 58:736-745.

95. Szyfter K, Szulc R, Mikstacki A, Stachecki I, Rydzanicz M, Jaloszynski P: Genotoxicity of inhalation anaesthetics: DNA lesions generated by sevoflurane in vitro and in vivo. J App/ Genet 2004, 45:369-374.

96. Graniewski J, Seifert B, Dyaczynska-Herman A, Karpel E, Zakrzewski A: Desflurane and sevoflurane - the influence on the selected components of the microsomal monooxygenases system. Eur J Anaesthesiol 2004, 21:127.

97. Baranowska K, Juszczyk G, Dmitruk I, Knapp M, Tycinska A, Jakubow P, Adamczuk A, Stankiewicz A, Hirnle T: Risk factors of neurological complications in cardiac surgery. Kardiol Pol 2012, 70:811-818.

98. Dabrowski W, Rzecki Z, Czajkowski M, Pilat J, Wacinski P, Kotlinska E, Sztanke M, Sztanke K, Stazka K, Pasternak K: Volatile anesthetics reduce biochemical markers of brain injury and brain magnesium disorders in patients undergoing coronary artery bypass graft surgery. J Cardiothorac Vasc Anesth 2012, 26:395-402.

99. Dabrowski W, Rzecki Z, Wosko J, Biernacka J, Kotlinska E, Czajkowski M: Volatile anaesthetics reduce serum $S 100 \beta$ concentrations in patients undergoing elective cardiac surgery. App/ Cardiopulm Pathophysiol 2010, 14:139-148.

100. Matchett GA, Allard MW, Martin RD, Zhang JH: Neuroprotective effect of volatile anesthetic agents: molecular mechanisms. Neurol Res 2009, 31:128-134.

101. Zhou Y, Lekic T, Fathali N, Ostrowski RP, Martin RD, Tang J, Zhang JH: Isoflurane posttreatment reduces neonatal hypoxic-ischemic brain injury in rats by the sphingosine-1-phosphate/phosphatidylinositol-3-kinase/ Akt pathway. Stroke 2010, 41:1521-1527.

102. Karwacki Z, Kowianski P, Dziewiatkowski J, Domaradzka-Pytel B, Ludkiewicz B, Wojcik S, Narkiewicz O, Morys J: The influence of sevoflurane on the reactivity of astrocytes in the course of the experimental intracerebral haemorrhage in rat. J Physiol Pharmacol 2005, 56:455-469.

103. Karwacki Z, Kowianski P, Dziewiatkowski J, Domaradzka-Pytel B, Ludkiewicz B, Wojcik S, Narkiewicz O, Morys J: Quantitative analysis of influence of sevoflurane on the reactivity of microglial cells in the course of the experimental model of intracerebral haemorrhage. Eur J Anaesthesiol 2006, 23:874-881.

104. Goździk W, Harbut P, Kübler A, Goździk W, Harbut P, Kübler A, Jezierski A, Goździk A, Pelczar M, Wysoczańska-Harbut J, Mierzchała M, Kustrzycki W: The influence of anaesthetic and ischaemic preconditioning on generation of reactive oxygen species in the coronary sinus in coronary artery bypass graft patients. Kardiochir i Torakochir Pol 2009, 6:272-278.

105. Woloszczuk-Gebicka B: Mivacurium infusion requirement and spontaneous recovery of neuromuscular transmission in children anaesthetized with nitrous oxide and fentanyl, halothane, isoflurane or sevoflurane. Paediatr Anaesth 2002, 12:511-518.

106. Woloszczuk-Gebicka B: Spontaneous recovery of neuromuscular transmission following rocuronium administration in children anaesthetized with nitrous oxide and fentanyl, halothane, isoflurane or sevoflurane. Eur J Anaesthesiol 2000, 17:138
107. Dziadek H, Cieślik T, Walawender T: The use of sedation in oral surgery. Dent Forum 2008, 36:73-77.

108. Wal A, Remiszewski A, Sosnowska-Boroszko A: Preliminary evaluation of using inhalation sedation with $\mathrm{N} 2 \mathrm{O}$ for children dental treatment. Nowa Stomatol 2000, 3:3-5.

109. Mychaskiw $G$ 2nd: Halogenated anesthetics and intensive care unit sedation: a note of caution. Anesthesiology 2011, 115:212-213. author reply 213-214.

110. Olszanski R, Radziwon P, Baj Z, Kaczmarek P, Giedrojc J, Galar M, Kloczko J: Changes in the extrinsic and intrinsic coagulation pathways in humans after decompression following saturation diving. Blood Coagul Fibrinolysis 2001, 12:269-274.

111. Olszanski R, Radziwon P, Siermontowski P, Lipska A, Laszczynska J, VanDamme-Ostapowicz K, Korsak J, Bujno M, Gosk P, Schenk JF: Trimix instead of air, decreases the effect of short-term hyperbaric exposures on platelet and fibrinolysis activation. Adv Med Sci 2010, 55:313-316.

112. Barg W, Janus A, Borodulin-Nadzieja L: Heliox as a driving gas for aerosols in asthma and COPD. Alergologia Info 2008, 3:132-136.

113. Szczapa T, Gadzinowski J: Helium and oxygen mixture in the treatment of respiratory disturbances in the newborn. Post Neonat 2005, 8:157-160.

114. Szczapa T, Gadzinowski J: Use of heliox in the management of neonates with meconium aspiration syndrome. Neonatology 2011, 100:265-270.

115. Oei GT, Weber NC, Hollmann MW, Preckel B: Cellular effects of helium in different organs. Anesthesiology 2010, 112:1503-1510.

116. Distante A, Dankowski R, Mincarone P, Leo CG, Gianicolo E, Voci P, Morales MA, Rovai D: Contrast echocardiography and medical economics: looking into the crystal ball. Eur Heart J Supp/ 2002, 4:C39-C47.

117. Schneider M: SonoVue, a new ultrasound contrast agent. Eur Radiol 1999 , 9:S347-S348.

118. Droste DW, Metz RJ: Clinical utility of echocontrast agents in neurosonology. Neurol Res 2004, 26:754-759.

119. Petelska AD, Janica JR, Kotynska J, Lebkowska U, Figaszewski ZA: The effect of contrast medium SonoVue(R) on the electric charge density of blood cells. J Membr Biol 2012, 245:15-22.

120. Kryza R, Dybiec E, Woźniak M, Wieczorek P, Polkowski W, Wierzbicki R: Contrast enhanced ultrasound with SonoVue in the diagnostics and differentiation of benign focal liver lesions. Ultrasonografia 2008, 33:21-27.

121. Lewicki A, Jędrzejczyk M, Jakubowski W, Pypno W, Kidawa A, Symonowicz P: The value of enhancement's type after administration of ultrasound contrast agent in differential diagnosis of solid renal lesions. Ultrasonografia 2008, 34:27-37.

122. Ustymowicz A, Janica J, Kowalewski R, Lewszuk A, Lukasiewicz A, Michalak P, Waszczeniuk-Sobotko O: Contrast-enhanced ultrasonography versus computed tomographic angiography in the monitoring of patients after endovascular repair of abdominal aortic aneurysm - preliminary experience. Nucl Med Rev Cent E Eur 2009, 12:95-98.

123. Dybiec E, Kryza R, Polkowski W, Wierzbicki R, Wieczorek P: The apllication of contrast enhanced ultrasound (CEUS) with SonoVue in the ultrasonographic diagnostics of metastatic liver lesions. Ultrasonografia 2007, 31:41-46.

124. Jędrzejczyk MWJ: Liver haemangiomas - gray-scale ultrasound images versus contrast enhanced ultrasound after administration of SonoVue. Diagnostic value in comparison to contrast enhanced computed tomography. Ultrasonografia 2009, 39:93-113.

doi:10.1186/2045-9912-3-17

Cite this article as: Ostrowski and Pucko: Research of medical gases in Poland. Medical Gas Research 2013 3:17. 